\title{
TECHNOLOGY: INCREASING CITIZEN ENGAGEMENT AND ACCESS TO INFORMATION
}

\section{David S. Reed}

$\mathbf{T}$ he federal government has only scratched the surface of engaging citizens through technology. Most of what we have seen so far is just adding technology to existing forms of engagement: rulemaking comments can be submitted electronically, tweets and on-line chats supplement press releases and speeches.

\section{The Goals of Increasing Engagement through Technology}

The greater potential for engagement is enabling citizens to build new services on top of government systems, and to analyze the same data that government maintains for its internal use. This lets citizens not only comment to government, but co-produce government.

\section{Recommended Actions}

\section{Welcome the Civic Hackers}

The citizens who participate in this deeper level of engagement are often called civic hackers. Civic hackers work on public sector projects using technology, but outside the traditional structure of government systems development. While hacking can also refer to criminal activity, civic hacking has gained enough legitimacy for the White House to host several hackathons. ${ }^{1}$

Civic hackers can operate as networks of individual enthusiasts, as nonprofit organizations, or occasionally as businesses. Local government leaders have had some notable successes cooperating with civic hackers to leapfrog the business-as-usual approach of government and its contractors. For example, GetCalFresh.org provides a simpler, quicker online process to apply for food stamps in six California counties. It was developed by Code for America, a civic hacking nonprofit, in cooperation with the counties. ${ }^{2}$

\footnotetext{
${ }^{1}$ White House, "Leadership and Policy Hackathon," The White House, accessed September 9, 2016, https://www.whitehouse.gov/node/345151; White House, "White House Foster Care \& Technology Hackathon," The White House, accessed September 9, 2016, https://www.whitehouse.gov/node/355016; White House, "Wrap Up: A Hackathon Here at the White House," Whitehouse.gov, June 3, 2014, https://www.whitehouse.gov/blog/2014/06/03/hackathon-here-white-house. ${ }^{2}$ Code for America, "California Counties Make It Easier to Apply for CalFresh," Code for America, accessed September 12, 2016, https://www.codeforamerica.org/featured-stories/counties-make-it-easy-to-apply-forcalfresh.
} 
Civic hackers generally do not charge the governments they work with. ${ }^{3}$ But for the engagement to produce results, the government may have to discuss its internal processes with the civic hackers at the same nuts-and-bolts level that they are only used to sharing with contractors.

Whether a government leader can benefit from civic hackers depends on whether she is willing to participate in disruptive improvement. For example, some state governments have threatened and even sued civic hackers for posting the state's codified laws on the internet, because the state or its contractor claimed copyright. ${ }^{4}$ But when civic hackers wanted to use the District of Columbia code without the restrictions imposed by DC's contractor, the General Counsel of DC's legislature found a contract loophole that allowed him to put a copy in the public domain. Civic hackers then created free software for searching, citing and analyzing the code with features the contractor did not offer, which has been used by both the public and the DC government itself. ${ }^{5}$

\section{Eat Your Own Dog Food}

“Eating your own dog food" is a software developers' term for using the product that you make. A developer who uses her own software day in and day out will become aware of all the problems users encounter, and will be more motivated to fix them. But the federal government has generally not let citizens engage with the same databases it maintains for its own use. Instead it released special data sets for public engagement, which are often low quality. As one user put it:

"The kaleidoscope of data formats in open data portals like data.gov might politely be called 'obscure', and perhaps more accurately, 'perversely unusable'. Some of the data hasn't been updated since first publication, and is quite positively too stale to use. If documentation exists, most of the time it's incomprehensible.”6

A government leader who wants meaningful citizen engagement will assure that when her agency's data systems are created or upgraded, they are built to allow sharing with citizens. This will require that each type of data in the system (i.e., each field) is tagged as to whether it can be shown to the public or must be blocked due to personal privacy, commercial trade secrets, public safety, etc. Making the protection for each type of data explicit will be a big change for agencies who practice "security through obscurity"; that is, making it difficult for citizens to obtain agency information in general, or even to know what information the

\footnotetext{
${ }^{3}$ One exception is that Code for American charges $\$ 250,000$ to assign a full-time Fellow for 11 months. But their volunteer "brigades" work with governments for free. Code for America, "Partner with Us," Code for America, accessed September 12, 2016, https://www.codeforamerica.org/join-us/partner-with-us.

${ }^{4}$ Mike Masnick, "State Of Georgia Sues Carl Malamud For Copyright Infringement For Publishing The State's Own Laws," Techdirt., July 24, 2015, https://www.techdirt.com/articles/20150723/17125231743/state-georgia-suescarl-malamud-copyright-infringement-publishing-states-own-laws.shtml.

${ }^{5}$ Michael Grass, "The Ultimate in Open Government: Unlocking the Laws," Government Executive, July 8, 2014, http://www.govexec.com/state-local/2014/07/ultimate-open-government-unlocking-laws/87997/.

${ }^{6}$ Anthea Watson Strong, "Hey Uncle Sam, Eat Your Own Dogfood - TheLi.st @ Medium - Medium," Medium, September 25, 2014, https://medium.com/@antheaws/hey-uncle-sam-eat-your-own-dogfood-9f0c110c13c8.
} 
agency has, on the rationale of protecting the specific pieces of information that should not be released.

Meaningful engagement with government data also requires that citizens can access it in a way that is useful for doing analysis or building services. Making data available as images of printed reports doesn't meet this requirement, nor do government web sites that only allow users to manually enter searches to obtain a few records at a time. One approach that works is letting citizens download the complete data file, a feature called "bulk download". A more sophisticated approach is for the government database to provide an application programming interface (API), which allows citizen-built applications to search and retrieve from the database over the internet without any manual steps.

When a government leader makes her agency's databases shareable with citizens, this will also make the databases more reliable for the agency. Systems that rely on security by obscurity are vulnerable to data breaches. Systems that are poorly documented and use nonstandard data formats hold the agency hostage to one or a few individuals who can make them work. Citizens who want to engage with the agency's data are free consultants to report these problems, if a government leader is willing to listen.

\section{Don’t Panic about Guerrilla Government}

Among the citizens who are most knowledgeable about an agency's issues, and likely to care about them, are the agency's own employees. In the past, government employees engaging as private citizens were viewed as a problem, so-called "guerrilla government". ${ }^{7}$ But technology is making off-the-clock engagement by government employees both inevitable and productive.

It is inevitable because technology makes it easy for government workers to engage across the silos of agency hierarchies. Email lists and on-line forums link workers across government who specialize in accessibility for disabled persons, data science, and any number of other functions. ${ }^{8}$ This encourages workers to identify with the mission of their professional specialty, not only the wishes of their supervisors. Technology also facilitates engagement among geographically dispersed workers. In June 2016, 51 State Department diplomats stationed around the world issued a joint memo dissenting from U.S. policy in Syria. While dissent memos in the State Department are not new, the number of employees who collaborated on this one was unprecedented, and gave it more influence. ${ }^{9}$

Engagement by government workers outside their jobs is productive in several ways. They can create innovations on their own time that official channels won't. For example, the database that

\footnotetext{
${ }^{7}$ Rosemary O'Leary, The Ethics of Dissent: Managing Guerrilla Government (CQ Press, 2006).

${ }^{8}$ An incomplete list is at digitalgov, "Communities," DigitalGov, November 17, 2013, https://www.digitalgov.gov/communities/.

${ }^{9}$ Mark Landler, "51 U.S. Diplomats Urge Strikes Against Assad in Syria," The New York Times, June 16, 2016, http://www.nytimes.com/2016/06/17/world/middleeast/syria-assad-obama-airstrikes-diplomats-memo.html.
} 
allows searching Inspector General reports across federal agencies is not a government project. It is a volunteer project led by a government employee on his own time. ${ }^{10}$

Workers engaging outside their jobs can make an agency more attractive to employees, potential employees, and constituencies. The General Services Administration's “18F” innovation office is noted for its employees' copious interactions with the broader technology community through both official and personal blogs, tweets, conference participation, etc. Not all the unofficial communication will be on-message from the agency's standpoint, but the overall result is to encourage talented workers to join and stay, and to improve the public's perception of the office.

A government leader observing engagement outside the job by her agency's employees has some necessary concerns. Employees' obligation to protect legitimately secret information must be made clear and enforced for their outside engagement just as when they are working. Employees should not give the impression they are speaking for the agency when they are not. But a government leader should not fight a doomed rear-guard action trying to suppress the fact that some citizens have different views than her agency's official position, even some citizens who work at the agency.

\section{Conclusion}

Technology is making the walls between government and citizens more porous. Information flows both ways through the countless channels that the internet enables. For a government official, this is an opportunity to overcome entrenched practices and make her agency more effective and efficient. The risky strategy is to try to hold off disruptive improvement, like taxi monopolies trying to hold off Uber. That strategy would have a government leader sacrifice performance improvements for an illusion of control.

\footnotetext{
${ }^{10}$ Eric Mill, “Opening up Government Reports through Teamwork and Open Data," OpenGov Voices, November 7, 2014, http://sunlightfoundation.com/blog/2014/11/07/opengov-voices-opening-up-government-reports-throughteamwork-and-open-data/.
} 